\title{
The Effect of Motivation on Employee Performance
}

\section{Yeti Kuswati}

Faculty Public and Administration, Majalengka University, Indonesia

yeti.kuswati@yahoo.co.id

\section{Abstract}

This research is motivated by the decline of employee performance over a period of time which results in the realization of the work not fully achieving the specified targets. The decline of employee performance is suspected by the decrease in the level of motivation possessed by the employee. The purpose of this study is to empirically prove that motivational factors have an influence on employee performance both descriptively and verifiatively. The research method used is descriptive method and survey method with quantitative data processing and analysis through parametric statistical approaches, the calculation of using SPSS 16 program tools. While the parameters used are employee motivation and performance based on respondents perceptions with sampling techniques carried out in random sampling. From the research results obtained that the effect of motivation on employee performance is quite good.

\section{Keywords}

motivation; performance;

organizational factors

\section{Introduction}

The decentralization policy by the central government to the regions, namely by the implementation of regional autonomy, makes each region have considerable authority in making decisions that are considered in accordance with regional needs. This is possible due to the wide variety of new authorities held by regional governments. With this very fundamental change, it requires the region's readiness to implement it as well as possible for all government affairs that become regional household affairs. Some aspects that must be prepared are human resources, financial resources, facilities and infrastructure as well as the organization and management. The readiness of the human resources of the regional government apparatus, especially related to the professionalism of the government apparatus, is something that absolutely must be carried out, so that in the implementation of regional autonomy, it is supported by the existence of the regional government apparatus that has the ability and spirit of performance in carrying out the tasks. Human resources that have performance are assets for organizations because they have an impact on improving organizational quality, especially government organizations that prioritize service aspects (Riantoputra, 2013; Altrasi and College, 2014; Karyono, 2018).

Thus, the government absolutely must carry out the guidance of the regional government apparatus that is directed and integrated in order to improve the professionalism, capability, and spirit of the performance of the regional government apparatus, in carrying out development tasks. One of the improvements in employee performance can be done by increasing the motivation factor. Several studies have shown empirically that motivational factors are very positive in improving employee performance (Jayaweera, 2015; Ghaffari, Burgoyne and Nazri, 2017; Ghaffari, Sara., Shah, Ishak Mad., John Burgoyne., 2020). 
Employee performance is closely related to the results of one's work in an organization or company. The results of the work can involve quality, quantity, and timeliness, but performance evaluation in a company's organization is key in employee development. Performance evaluation is in principle a manifestation ofan employee's performance appraisal form (Irfansyah, 2020). The achievement of employee performance in Majalengka Regency Education Office of is largely determined by the ability of the Head of Office in leading, fostering, and directing employees in carrying out their duties that is by carrying out motivation. Motivation is one of the organic functions of management. The success of the implementation of the above motivation depends on the ability of the Head of Service in implementing the principles of motivation. In this study, work motivation consists of the principle of participation, the principle of communication, the principle of recognition, the principle of delegated authority and the principle of reciprocity (Hasibuan, 2006), while performance refers to aspects of quantity, quality, productivity, timeliness and effectiveness (Wibowo, 2010 ). Good motivation can strengthen commitment (Sohail et al., 2014; Burns and Alexander, 2020) and lead to improved performance (Joseph, 2015), while good performance can improve organizational performance (Bashaer and Singh, 2017) and lead to on satisfaction (Karyono, 2016). This research will answer the hypothesis about the effect of motivation on employee performance.

\section{Research Methods}

The research method that researchers use is a combination of descriptive methods and survey methods that research is conducted by plunging directly the field of data that occurs when the research is conducted to describe and find out and study the influence of variables, in this case the effect of motivation on employee performance at Majalengka Regency Education Office by processing and analyzing quantitative data through a parametric statistical approach. The population in this study 103 government officials from the Majalengka Regency Education Office and after sampling using the Slovin formula, the sample size was obtained as many as 82 people with sampling techniques using random sampling techniques. The questionnaire was used as the main instrument to collect a number of data relevant to the research needs. The way is by giving questions in writing to employees at Majalengka Regency Education Office as respondents. The hypothesis was tested with Pearson product moment (r) correlation techniques to test the relationship and continued with a simple regression analysis.

\section{Discussion}

This study produced several important findings including descriptive results of motivation and performance variables as well as the magnitude of influence given from motivational variables on employee performance. Entika (2019) states a person who need to achieve an objective accordingly, that particular person change the behavior added with commitment, enthusiasm and persistence Before analyzing the research data, the researcher first tests the validity and reliability of the research data. Test the validity, reliability and normality of data in this study using the moment product correlation. Validity test is done to see whether the instrument used measures what should be measured (Sugiyono, 2010: 93). To test the validity of each item item analysis is used, which correlates the score of each item with the total score which is the sum of each item score. Furthermore, the product moment correlation value of the results of the study is compared with $r_{\text {tabel }}$, if $r_{\text {count }}$ is greater than $r_{\text {tabel}}$, 
it means the product moment correlation for each statement is valid. Reliability test is the level of stability of a measuring device in measuring a symptom / event. The higher the reliability of a measuring device, the more stable it is. Instrument reliability test is carried out on items of questionnaire questions that are declared valid, thus invalid items do not need to be tested for reality or in other words invalid items are removed / discarded. The normality test requires that the behavior of random disturbance elements be normally distributed or close to normal. To find out whether the data is normally distributed or not, then the data normality test is used. The results of the validity test of reliability and normality of data are as follows.

Table 1. The validity of motivational instruments test

\begin{tabular}{|c|c|c|c|c|}
\hline Dimensions & Indicators & $\mathbf{R}_{\mathbf{x y}}$ & $\mathbf{R}_{\text {table }}$ & Information \\
\hline $\begin{array}{l}\text { 1. The principle } \\
\text { of participation }\end{array}$ & $\begin{array}{l}\text { - Involve employees in decision } \\
\text { making } \\
\text { - Be open to suggestions or ideas } \\
\text { from employees }\end{array}$ & $\begin{array}{l}0,240 \\
0,390\end{array}$ & $\begin{array}{l}0,215 \\
0,215\end{array}$ & $\begin{array}{l}\text { Valid } \\
\text { Valid }\end{array}$ \\
\hline $\begin{array}{l}\text { 2. Principle of } \\
\text { Communication }\end{array}$ & $\begin{array}{l}\text { - Creating two-way communication } \\
\text { - Using writing that is easy to } \\
\text { understand }\end{array}$ & $\begin{array}{l}0,339 \\
0,677\end{array}$ & $\begin{array}{l}0,215 \\
0,215\end{array}$ & $\begin{array}{l}\text { Valid } \\
\text { Valid }\end{array}$ \\
\hline $\begin{array}{l}\text { 3. Principle of } \\
\text { Recognition }\end{array}$ & $\begin{array}{l}\text { - Award for employees who excel } \\
\text { - Creating healthy competition }\end{array}$ & $\begin{array}{l}0,510 \\
0,237\end{array}$ & $\begin{array}{l}0,215 \\
0,215\end{array}$ & $\begin{array}{l}\text { Valid } \\
\text { Valid }\end{array}$ \\
\hline $\begin{array}{l}\text { 4. The principle } \\
\text { of delegated } \\
\text { authority }\end{array}$ & $\begin{array}{l}\text { - Authority is given to the right } \\
\text { person } \\
\text { - The granting of authority } \\
\text { accompanied by responsibilities }\end{array}$ & $\begin{array}{l}0,258 \\
0,262\end{array}$ & $\begin{array}{l}0,215 \\
0,215\end{array}$ & $\begin{array}{l}\text { Valid } \\
\text { Valid }\end{array}$ \\
\hline $\begin{array}{l}\text { 5. Principle of } \\
\text { mutual attention }\end{array}$ & $\begin{array}{l}\text { - -Creating a harmonious work } \\
\text { atmosphere. } \\
\text { - Trying to meet the needs of } \\
\text { employees. }\end{array}$ & $\begin{array}{l}0,634 \\
0,621\end{array}$ & $\begin{array}{l}0,215 \\
0,215\end{array}$ & $\begin{array}{l}\text { Valid } \\
\text { Valid }\end{array}$ \\
\hline
\end{tabular}

Source: Research results, 2017

Based on the results of data processing with instrument validity, the results obtained are that of the 10 question items, all items are declared valid. This is evidenced by the $r_{\text {count }}$ value for all instruments $>r_{\text {table. }}$. The lowest $r_{\text {count }}$ value is found in the recognition principle indicator, the recognition principle is 0.237 , and the $r_{\text {count }}$ value for all instruments $>r_{\text {table. }}$. The highest $r_{\text {count }}$ value is in the communication principle indicator, using writing that is easy to understand that is equal to 0.677 . Furthermore, the results of testing the validity of the instruments of the performance variables can be seen as follows:

Table 2. The validity of motivational instruments test

\begin{tabular}{|l|l|c|c|c|}
\hline Dimensions & \multicolumn{1}{|c|}{ Indicators } & $\mathbf{R}_{\mathbf{x y}}$ & $\mathbf{R}_{\text {tabel }}$ & Information \\
\hline 1. Quantity & $\begin{array}{l}\text {-The performance of workers } \\
\text { performed in accordance with } \\
\text { predetermined targets }\end{array}$ & 0,541 & 0,215 & Valid \\
$\begin{array}{l}\text {-The number of employee } \\
\text { attendance is increasing }\end{array}$ & 0,588 & 0,215 & Valid \\
\hline
\end{tabular}




\begin{tabular}{|l|l|c|c|c|}
\hline 2. Quality & $\begin{array}{l}\text { - Work performed in accordance } \\
\text { with work standards and } \\
\text { guidelines }\end{array}$ & 0,334 & 0,215 & Valid \\
\hline $\begin{array}{l}\text {-The work results meet the level of } \\
\text { satisfaction }\end{array}$ & 0,577 & 0,215 & Valid \\
\hline 3. Productivity & $\begin{array}{l}\text { - The results of the work done } \\
\text { provide satisfaction for the } \\
\text { organization and the community } \\
\text { - Increase morale }\end{array}$ & 0,377 & 0,215 & Valid \\
\hline Timeliness & $\begin{array}{l}\text {-The implementation of the work } \\
\text { in accordance with the time and } \\
\text { conditions set } \\
\text { - Discipline in the implementation } \\
\text { of work }\end{array}$ & 0,350 & 0,215 & Valid \\
\hline $\begin{array}{l}\text { There is no waste in the } \\
\text { execution of work }\end{array}$ & $\begin{array}{l}\text { - Guided by the budget that has } \\
\text { been set }\end{array}$ & 0,225 & 0,215 & Valid \\
\hline
\end{tabular}

Source: Research results, 2017

Based on the results of data processing with instrument validity, the results obtained are that of the 10 question items, all items are declared valid. This is evidenced by the $r_{\text {count }}$ value for all instruments $>r_{\text {table }}$. The lowest $r_{\text {count }}$ value is in the effectiveness dimension with the indicator that there is no waste in carrying out the work, that is equal to 0.225 , and the $r_{\text {count }}$ value for all instruments $>r_{\text {table. }}$. The highest $r$-count value is in the quantity dimension with an indicator of the number of attendances increasing by 0.588 .

Reliability is a tool for measuring a questionnaire which is a measurement tool for constructs or variables. A questionnaire is said to be reliable or reliable if a person's answer to a question is consistent or stable over time (Ghozali, 2001). Reliability test is the level of stability of a measuring device in measuring a symptom / event. The higher the reliability of a measuring device, the more stable it is. Instrument reliability test is carried out on items of questionnaire questions that are declared valid, thus invalid items do not need to be tested for reality or in other words invalid items are removed / discarded. Reliability testing of research instruments using SPSS results can be seen in the table below:

Table 3. The reliability of research variables test

\begin{tabular}{|l|l|c|l|}
\hline Variables & Cronbach Alpha & Critical value & Status \\
\hline Motivation & 0,709 & 0,678 & Reliable \\
\hline Employee Performance & 0,823 & 0,678 & Reliable \\
\hline
\end{tabular}

Source: Ankle processing, 2017

These results indicate that all variables have considerable reliability that is above 0.678 so that it can be said that all measuring concepts of each variable from the questionnaire are reliable so that henceforth the items in each of the concepts of these variables are worthy of being used as a measuring tool.

Normality test requires that the behavior of random disturbance elements be normally distributed or close to normal. To find out whether the data is normally distributed or not, then the data normality test is used. Data normality test is calculated using SPSS as follows: 
Table 4. Data normality test results

\begin{tabular}{|l|l|c|c|}
\hline \multicolumn{1}{|c|}{ Variables } & P-Value & Critical value & Information \\
\hline Motivation & 0,156 & 0,05 & Normal \\
\hline Employee Performance & 0,113 & 0,05 & \\
\hline
\end{tabular}

Source: Research Results, 2017

Based on tabel above, it can be obtained that all the research variables have values > 0.05 , so it can be concluded that all variables have normal distribution. The value in the highest normality test is found in the motivation variable with a p-value of 0.156 , and the lowest normality value obtained in the performance variable with a $p$-value of 0.113 . After the data has fulfilled the validity, reliability and data normality requirements, the next step is to carry out a descriptive and verification analysis. Descriptive research results on the motivational variables which are divided into several research parameters including the principle of including, the principle of communication, the principle of recognition, the principle of delegation authority and the principle of public attention are explained in the following table.

Table 5. Research Results of Motivational Variables Description

\begin{tabular}{|l|c|c|c|}
\hline \multicolumn{1}{|c|}{ Dimensions } & Avarage & Std Deviation & Information \\
\hline The principle of participation & 3,22 & 0,753 & Good \\
\hline The principle of communication & 2,78 & 0,742 & Good \\
\hline The principle of recognition & 2,86 & 0,785 & Good \\
\hline The principle of delegated authority & 3,04 & 0,865 & Good \\
\hline The principle of attention and reciprocity & 2,74 & 0,765 & Good \\
\hline \multicolumn{1}{|c|}{ Motivation Variable } & $\mathbf{2 , 9}$ & $\mathbf{0 , 7 8}$ & Good \\
\hline
\end{tabular}

Source: Research questionnaire processed, 2017

Table 5, it is known the motivational variables formed by the dimensions namely the principle of participation, the principle of communication, the principle of recognition, the principle of delegation aut delegated authority hority and the principle of attention and reciprocity are categorized quite good. However, if analyzed based on dimensions, the average value of dimensions is between 2.9 and standard deviation of 0.78 so that respondents' answers are quite good. Based on table 5 the principle dimension of reciprocity has the lowest value of 2.74. This can be described that the principle of attention and reciprocity has not been achieved optimally. The weakness of the principle of attention and reciprocity must be a concern that is trying to meet the needs of employees.

Table 6. Research Results of Performance Variables Description

\begin{tabular}{|l|c|c|c|}
\hline \multicolumn{1}{|c|}{ Dimensions } & Avarage & Std Deviation & Information \\
\hline Quantity & 2,98 & 0,785 & Good \\
\hline Quality & 3,05 & 0,756 & Good \\
\hline Productivity & 2,83 & 0,773 & Good \\
\hline Timeliness & 2,95 & 0,781 & Good \\
\hline Effectiveness & 2,99 & 0,797 & Good \\
\hline \multicolumn{1}{|c|}{ Performance Variable } & $\mathbf{2 , 9}$ & $\mathbf{0 , 7 8}$ & Good \\
\hline
\end{tabular}

Source: Research questionnaire processed, 2017 
Table 6 shows the performance variables formed by the dimensions namely quantity, quality, productivity, timeliness and effectiveness are categorized quite good. However, if analyzed based on dimensions, the average value of dimensions is between 2.95 and the standard deviation of 0.78 so that respondents' answers are quite good. Based on table 6 the productivity dimension has the lowest value of 2.83 . This can be described that productivity has not been achieved optimally. Weaknesses of this productivity must be a concern, namely the results of the work carried out to give satisfaction to employees at the Department of Education Majalengka Regency. Based on the results of the verification discussion, the following conclusions can be illustrated:

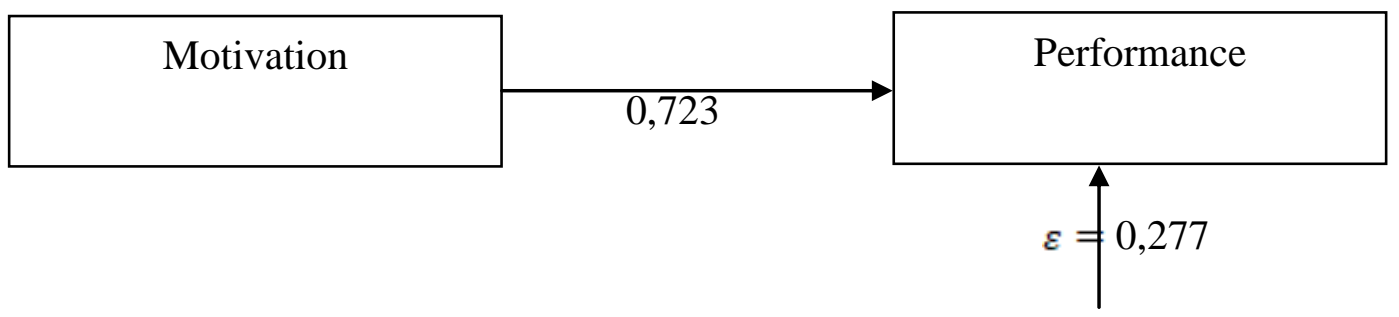

Figure 1. The Summary of Verification Results

Source: 2017 data processing

Motivation has a positive effect on performance. The results give meaning that the role of motivation becomes a supporting factor in an organization both government and private especially in improving performance. Empirical findings indicate that the direct influence of motivation on performance has an influence. This is based on the relationship between performance and motivation. The findings of this study are in line with several previous studies which have proven in advance that motivation has a significant effect on employee performance both directly (Elvina and Chao, 2019) as well as acting as mediators (Jayaweera, 2015). In addition, the motivation possessed by employees further has the ability to improve organizational performance (Dobre, 2013). However, the results of this study found that employee motivation cannot be separated from the leaders involved in it who have the function to provide motivation both verbally and in writing. The importance of the role of leadership in providing motivation is in accordance with previous research findings which show that motivation is closely related to leadership factors (Hasan and Khajeh, 2018). Muhammada (2019) states leadership style is a pattern of behavior of a typical leader when he influences his people, what is chosen by the leader to be done, the way the leader acts in influencing the group to form the leadership of his leader.

From the results of the analysis prove that motivation has an average value of 2.9, thus motivation can be categorized quite good. This suggests that motivation has a very important role for employee performance at Majalengka Regecy Education Office, which is formed based on the dimensions: the principle of participation, the principle of communication, the principle of recognition, the principle of delegated authority as well as the principle of attention and reciprocity have not been fully applied in the implementation of motivation by Head of Majalengka Regency Education Office, even though this dimension has a very important role to support the formation of effective motivation in the process of achieving goals and the process of organizing education in Majalengka Regency Education Office.

The analysis proves that the average value of performance is 2.95 , so the performance can be categorized quite good. This suggests that the performance of Majalengka Regency Education Office was considered quite good and was in accordance with the performance standards set based on the dimensions of quantity, quality, productivity, timeliness and 
effectiveness. Even though it is categorized quite good, there is one dimension that has a low average value, namely the productivity dimension with a value of 2.83 . This proves that the performance of Majalengka Regency Education Office is not optimal and needs to be improved even though this dimension in general has a very important role to encourage the realization of quality standards of employee performance at Majalengka Regency Education Office.

\section{Conclusion}

At the end of this study, it can be concluded that the motivation possessed by employees in Majalengka Regency Education Office is mostly in the quite good category with an average value of 2.84 and a standard deviation of 0.78 , however there are some weaknesses based on research findings this is a weakness in the aspect of involving opportunities for employees to participate in the decision making process and being open to suggestions or opinions expressed by employees and providing opportunities for employees to participate in the decision making process and being open to suggestions or opinions raised by employees that are still not optimal . Research findings on employee performance show that most of the employees are in quite good performance with an average value of 2.95 and a standard deviation value of 0.78 , however there are still some weaknesses including in the aspects of employee productivity and discipline. Verification research results show that motivation is empirically proven to have a strong and positive influence on employee performance.

The results of this study provide recommendations that Majalengka Regency Education Office should focus on increasing work motivation by considering physiological needs such as providing incentives or transportation fees, food allowances and so forth. Determination of the awarding of compensation depends on the contribution made to the Majalengka Regency Education Office. In improving employee performance, the Head of Majalengka Regency Education Office should be able to provide challenging tasks so that employees can develop creativity in doing their work which can be done by providing opportunities for employees to attend education and training, so that employees' abilities can be increased in the implementation of their work, and always providing guidance, direction and reprimand to employees.

\section{References}

Altrasi, M. A. and College, H. C. (2014) 'Determinants of Performance among Public Sector Managers in Saudi Arabia: An Analysis of the Organizational Factors and Job Attitudes', Middle-East Journal of Scientific Research 22, 22(3), pp. 409-416. doi: 10.5829/idosi.mejsr.2014.22.03.21902.

Bashaer, A. and Singh, S. (2017) 'Determinants of organizational performance : a proposed framework International Journal of Productivity and Performance Management Article information ':, International Journal of Productivity and Performance Management, 65(December), pp. 844-859. doi: 10.1108/IJPPM-02-2016-0038.

Burns, L. R. and Alexander, J. A. (2020) 'The Impact of Employee Motivation on Organizational Commitment The Impact of Employee Motivation on Organizational Commitment', European Journal of Business and Management, 9(15), pp. 134-137.

Dobre, O. (2013) 'Employee motivation and organizational performance', Review of Applied Socio- Economic Research, 5(1), pp. 53-60. 
Elvina, S. and Chao, L. Z. (2019) 'A Study on the relationship between employee motivation and work performance', IOSR Journal of Business and Management (IOSR-JBM), 21(3), pp. 59-68. doi: 10.9790/487X-2103025968.

Entika, H.S.A., and Ling, Y.L. (2019). The Importance of Immediate Constructive Feedback on Students' Instrumental Motivation in Speaking in English. Britain International of Linguistics, Arts and Education (BIoLAE) Journal, 1-7.

Ghaffari, Sara., Shah, Ishak Mad., John Burgoyne., J. R. S. (2020) 'The Influence of Motivation on Job Performance: A Case Study at Universiti Teknologi Malaysia The Influence of Motivation on J ob Performance : Universiti Teknologi Malaysia A Case Study at', Australian Journal of Basic and Applied Sciences, 11(4), pp. 92-99. Available at: http://creativecommons.org/licenses/by/4.0/ .

Ghaffari, S., Burgoyne, J. and Nazri, M. (2017) 'The Influence of Motivation on Job Performance: A Case Study at Universiti The Influence of Motivation on Job Performance: A Case Study at Universiti Teknologi Malaysia', Australian Journal of Basic and Applied Sciences, 11(4), pp. 92-99.

Hasan, E. and Khajeh, A. (2018) 'Impact of Leadership Styles on Organizational Performance', Journal of Human Resources Management Research, 20(18), pp. 1-10. doi: $10.5171 / 2018.687849$.

Hasibuan, M. S. . (2006) Manajemen Dasar, Pengertian, dan. Masalah,Edisi Revisi. Jakarta: Bumi Aksara.

Irfansyah. (2020). TheDutiesandFunctions Performance of Aceh Human Resources Improvement Institutions inScholarship Study Program Implementation in Aceh Government. Britain International of Humanties and Social Sciences (BIoHS) Journal, 160-165.

Jayaweera, T. (2015) 'Impact of Work Environmental Factors on Job Performance, Mediating Role of Work Motivation : A Study of Hotel Sector in', International Journal of Business and Management, 10(3), pp. 271-278. doi: 10.5539/ijbm.v10n3p271.

Joseph, B. (2015) 'The effect of employees ' motivation on organizational performance', Journal of Public Administration and Policy Research, 7(May), pp. 62-75. doi: 10.5897/JPAPR2014.0300.

Karyono, O. (2018) 'Faktor determinan motivasi dan disiplin kerja terhadap kinerja pegawai serta dampaknya pada mutu pelayanan pada dinas pemuda, olahraga, budaya dan pariwisata (disporabudpar) kabupaten majalengka', Proceeding STIMA, 1(1), pp. 348359.

Karyono, O. dan M. P. (2016) 'Kepuasan nasabah diukur dari kinerja pelayanan dan kinerja karyawan', J-Ensitec, 02(02), pp. 32-37.

Muhammad, and Hidayat, R. (2019). The Relationship between the Transformational Leadership Style of Madrasah Head and Work Discipline with the Performance of Teachers atMTsN Lima Puluh Batu Bara. Britain International of Linguistics, Arts and Education Sciences (BIoLAE) Journal, 175-182.

Riantoputra, C. D. S. (2013) 'Factors Influencing Individual Performance In An Indonesian Government Office', The South East Asian Journal of Management, 7(2), pp. 51-60. Available at: http://journal.ui.ac.id/index.php/tseajm/article/view/2051/1560.

Sohail, B. A. et al. (2014) 'Effect of Work Motivation and Organizational Commitment on Job Satisfaction: (A Case of Education Industry in Pakistan)', Global Journal of Management and Business Research: A Administration and Management, 14(6).

Wibowo (2010) Manajemen Kinerja. Jakarta: Rajawali Press. Adisasmita. 